\title{
Zonder zon groeit er niets
}

Citation for published version (APA):

Nieuwenhuijzen Kruseman, A. C. (2012). Zonder zon groeit er niets: Afscheidsrede van Prof. Dr. A.C. Nieuwenhuijzen Kruseman. (1 ed.) Universiteit Maastricht. https://doi.org/10.26481/spe.20121214ank

Document status and date:

Published: 14/12/2012

DOI:

10.26481/spe.20121214ank

Document Version:

Publisher's PDF, also known as Version of record

\section{Please check the document version of this publication:}

- A submitted manuscript is the version of the article upon submission and before peer-review. There can be important differences between the submitted version and the official published version of record.

People interested in the research are advised to contact the author for the final version of the publication, or visit the DOI to the publisher's website.

- The final author version and the galley proof are versions of the publication after peer review.

- The final published version features the final layout of the paper including the volume, issue and page numbers.

Link to publication

\footnotetext{
General rights rights.

- You may freely distribute the URL identifying the publication in the public portal. please follow below link for the End User Agreement:

www.umlib.nl/taverne-license

Take down policy

If you believe that this document breaches copyright please contact us at:

repository@maastrichtuniversity.nl

providing details and we will investigate your claim.
}

Copyright and moral rights for the publications made accessible in the public portal are retained by the authors and/or other copyright owners and it is a condition of accessing publications that users recognise and abide by the legal requirements associated with these

- Users may download and print one copy of any publication from the public portal for the purpose of private study or research.

- You may not further distribute the material or use it for any profit-making activity or commercial gain

If the publication is distributed under the terms of Article $25 \mathrm{fa}$ of the Dutch Copyright Act, indicated by the "Taverne" license above, 
Prof. Dr A.C. Nieuwenhuijzen Kruseman

Faculty of Health, Medicine and Life Sciences

\section{Zonder zon groeit er niets}




\section{Zonder zon groeit er niets}

Prof. Dr A.C. Nieuwenhuijzen Kruseman

hoogleraar Interne Geneeskunde, in het bijzonder de Endocrinologie

Afscheidscollege Faculty of Health, Medicine and Life Sciences, tevens Flendrig-lecture in het kader van de wetenschapsdag van de afdeling Interne Geneeskunde van het Maastricht Universitair Medisch Centrum+

Universiteit Maastricht, 14 december 2012 
Meneer de rector magnificus, dames en heren,

Welkom bij dit afscheidscollege. Uw belangstelling daarvoor stel ik zeer op prijs. Dit wordt geen echt college, meer een tour langs een aantal stations die ik de afgelopen 46 jaar heb aangedaan. Het eerste station is de Universiteit Leiden waar ik in 1966 medicijnen ging studeren. Mijn eerste kamer was in de sterflat aan de Klikspaanweg. Klikspaan was het pseudoniem waaronder Johannes Kneppelhout in de negentiende eeuw op humoristische wijze zijn studentenleven heeft beschreven. Ik heb mij tijdens mijn eerste studiejaar zeer laten inspireren door de studenten-typen van Klikspaan $^{1}$ en haalde dat jaar dan ook vooral levenspunten, weinig studiepunten. Niemand vond dat erg. Ik was ook bepaald geen uitzondering. In 1967 begon ik dus vrolijk opnieuw. Inmiddels was ik verhuisd naar de Utrechtsche Veer en lid geworden van het medisch dispuut Donders. Dit dispuut is bepalend geweest voor de jaren die volgden. In de eerste plaats omdat ik daar mijn vrouw Hieke heb ontmoet. In de tweede plaats door de mentor van het dispuut, Roelof Willighagen, die lector in de pathologische anatomie was. Willighagen hield erg van bier en dan ben je al snel populair bij studenten. Maar hij wist ook anderszins te inspireren. Daardoor haalde ik bij mijn kandidaatsexamen een hoog cijfer voor pathologie en kon ik student-assistent worden in het laboratorium Histochemie van Willighagen. Willighagen zette mij op onderzoek naar hormoonproductie door longtumoren, waarmee mijn belangstelling voor de endocrinologie begon. Hij gaf mij alle vrijheid om te spelen met reagentia, weefsels en microscopen. Dat leidde zomaar tot een promotieonderzoek over de immuunlocalisatie van hormonen in hypofyseweefsel. Aan collegelopen kwam ik daardoor niet meer toe. In Maastricht heb ik later geleerd dat hoorcolleges ook weinig zin hebben.

Ik wisselde mijn studieverplichtingen dus af met promotieonderzoek in het laboratorium. En speelde muziek in Sempre Crescendo en het Nederlands Studenten Orkest. Gedurende een aantal maanden deed ik ook nog obducties, omdat mij dat nuttig leek voor een aanstaand clinicus. Daardoor liep ik nogal wat vertraging op. In juni 19975 studeerde ik af en een jaar later begon ik met de internistenopleiding. Weliswaar gepromoveerd, maar tien jaar nadat ik met de medicijnenstudie begonnen was. Ik ben dus een echte langstudeerder geweest. Tegenwoordig heeft dat een negatieve connotatie. Destijds vond men dat ik mijn studietijd optimaal had benut.

Hiermee wil ik niet zeggen dat het vroeger allemaal beter was. Want dat is niet zo. Wij hadden alle mogelijkheden om ons te ontplooien, maar werden matig opgeleid. De studie was een hordeloop van theoretische vakken, zonder samenhang, en zonder onderwijs in praktische vaardigheden. Het vak leerde je tijdens de coschappen, zonder supervisie. Niet zelden heb ik naderhand in Maastricht aan coassistenten gevraagd mij bepaalde onderdelen van het lichamelijk onderzoek te demonstreren. Zij meenden dan dat zij getoetst werden en legden mij elke handeling stap voor stap uit, zoals hun dat in het Skillslab was geleerd. Zo hebben Maastrichtse coassistenten mij aan de hand van mijn patiëntproblemen geleerd wat ik tijdens mijn opleiding heb gemist.

Als lid van de Reviewcommissie Hoger Onderwijs, de zogenaamde commissie van Vught, heb ik het afgelopen jaar kunnen constateren dat het hoger onderwijs in de breedte enorm verbeterd en geprofessionaliseerd is. De studenten van nu hebben zeker niet te klagen over gebrek aan aandacht, begeleiding en structuur. De onderwijsfaciliteiten zijn om jaloers op te zijn. Vrijwel alle universiteiten nemen het onderwijs tegenwoordig serieus en streven naar verhoging van de kwaliteit en het rendement van het onderwijs. De tijd dat inspanningen voor onderwijs ondergeschikt werden geacht aan wetenschappelijk onderzoek is echt voorbij. Niettemin is er toch reden voor zorg. Mede naar aanleiding van onder meer het rapport van de commissie-Veerman vinden sommigen zelfs dat er sprake is van een crisis in het hoger onderwijs. Dat vind ik niet. Het hoger onderwijs staat er ook in internationaal verband goed voor. Alle Nederlandse universiteiten prijken in de top-200 van de Times Higher Education World University ranglijst. Dat is meer dan Frankrijk en Duitsland presteren. En dit zijn beide toch veel grotere landen met meer universiteiten. Nederland is zelfs na de Verenigde Staten en het Verenigd Koninkrijk het derde best vertegenwoordigde land in de wereldwijde top-200. Maar waakzaamheid is wel geboden en dat heeft vooral te maken met de wijze waarop de politiek naar het hoger onderwijs kijkt.

Hoger onderwijs lijkt namelijk meer en meer in de greep te komen van een economische benadering. In haar recente boek 'Niet voor de winst, waarom de democratie de geesteswetenschappen nodig heeft' noemt Martha Nussbaum ${ }^{2}$ dit 'winstgericht onderwijsbeleid'. Dat wil zeggen een onderwijsbeleid dat zich meer en meer richt op wat de kenniseconomie, het bedrijfsleven en de arbeidsmarkt nodig 
hebben. Ik heb dat ook ervaren in de Reviewcommissie. Daarin werd aansluiting van wetenschappelijk onderwijs en onderzoek op het topsectorenbeleid van het ministerie van Economische Zaken voor toekenning van een selectief budget twee maal zwaarder gewogen dan ambities en uitvoerbaarheid van andere taken in onderwijs en onderzoek. Ik wil niet ontkennen dat wetenschappelijk onderwijs en onderzoek een belangrijke bijdrage leveren aan economische ontwikkeling en innovatie, maar dit rechtvaardigt een dergelijke prioritering mijn inziens niet. De maatschappelijke betekenis van wetenschap reikt veel verder dan de economie en het bedrijfsleven. Wetenschap helpt ons om onszelf en de wereld beter te begrijpen. Een wetenschappelijke manier van denken, met haar onderzoekende houding en zelfkritiek, speelt immers een centrale rol in de vorming van jonge mensen, onze leiders van morgen. Wetenschap draagt voorts bij aan welzijn en gezondheid, aan de kwaliteit van politieke besluitvorming en aan het behoud van cultureel erfgoed. Al deze vormen van waarde kan de wetenschap alleen maar realiseren als ze zich vrij kan blijven ontwikkelen. Voor topsectoren zijn bètawetenschappen belangrijk. Voor de maatschappelijke dimensie van het hoger onderwijs hebben de alfa- en gammawetenschappen minstens zoveel waarde. De problemen van bijvoorbeeld de multiculturele samenleving en veiligheid op straat en een beter begrip voor wat anderen beweegt vallen niet onder de topsectoren, maar vergen wel wetenschappelijk onderzoek. Voor het functioneren van de democratie is het belangrijk dat jonge mensen voldoende kansen krijgen om zich te verdiepen in andere culturen, hun talen leren en geleerd wordt hoe kritische te reflecteren en argumenteren. Ik ben dan ook blij dat Karl Dittrich benoemd is tot voorzitter van de VSNU. Hij kent de universiteit, hij weet wat de maatschappelijke betekenis van een universiteit is, en houdt van de universiteit. Dat laatste is belangrijk. Want zonder liefde geen passie. Het is juist passie wat de school van Athene heeft gemaakt tot de universiteit van vandaag. Een solide basis waar nieuwe ideeën worden geboren, nieuwe ontwikkelingen in gang worden gezet en de geest van de leiders van morgen wordt geslepen en gepolijst. En dat moet vooral zo blijven.

Mijnheer de rector, als voorzitter van de KNMG heb ik de afgelopen jaren ruimschoots de gelegenheid gehad om de bokaal van de gezondheidszorg te bestuderen. Niet alleen in het hoger onderwijs, ook in de zorg doet Nederland het goed. En patiënten waarderen dat ook. Jaar in jaar uit staat Nederland bovenaan in de European Health Consumer Index. Volgens het Amerikaanse Commonwealthfund heeft Nederland het beste curatieve zorgstelsel. In vergelijking met de landen om ons heen is vooral de curatieve zorg sober en efficiënt. Per hoofd van de bevolking heeft Nederland minder artsen, minder ziekenhuisbedden, minder opnames in ziekenhuizen, een kortere ligduur en minder geneesmiddelengebruik. De eerstelijn lost veel zorgproblemen op, tegen lage kosten. Wachttijden zijn er nog steeds, maar wel veel minder dan vroeger en nu merendeels conform de Treeknorm. Het percentage patiënten dat vier of meer weken moet wachten voor een afspraak met een specialist is thans $30 \%$. Het percentage patiënten dat vier of meer maanden moet wachten op een operatie is $5 \%$. Wanneer echt nodig kan een consult met een specialist binnen een paar dagen of een operatie binnen een paar weken. De afname van wachttijden komt overigens niet door invoering van marktwerking, maar door aanpassing van het zorgbudget in de periode daarvóór door VWS-minister Els Borst.

De vraag is dan ook, is er een probleem? Mijn antwoord is ja. Met grote regelmaat worden er in de media incidenten gemeld. En er zijn ook structurele problemen of in aantocht. Aan de hand van een aantal voorbeelden wil ik dat toelichten.

\footnotetext{
Voorbeeld 1

In de afgelopen 150 jaar is de levensverwachting van de Nederlander drastisch gestegen. Dit is merendeels een gevolg van verbeterde hygiëne door de aanleg van de riolering en de aansluiting op gezuiverd kraanwater. Voorts betere voeding, betere woonomstandigheden en ontwikkelingen in de geneeskunde. In de negentiende eeuw waren infectieziekten de belangrijkste doodsoorzaak. De impact van een infectieziekte als tuberculose op het denken en doen van de samenleving was in die tijd enorm. Nu niet meer. Voor zolang als het duurt althans. Want door roekeloos gebruik van antibiotica in vooral de veeteelt bestaat er een reëel risico op een allesomvattende resistentie van micro-organismen voor antibiotica. Zover is het gelukkig nog niet. Op dit moment wordt de levensverwachting vooral bepaald door kanker en hart- en vaatziekten. Ook daarin worden grote vorderingen gemaakt. Om die reden stijgt de gemiddelde levensverwachting van de Nederlander nog steeds.
}

In vergelijking met de landen om ons heen is er echter iets aan de hand. Tot 1990 had Nederland de hoogste levensverwachting ter wereld. Sindsdien is de levensverwachting van 65-jarige Nederlanders echter een aantal jaren minder dan die van andere Europeanen. De vraag is hoe dat komt. 
Verschillen in levensverwachting zijn deels gerelateerd aan verschillen in sociaaleconomische status en opleidingsniveau. De levensverwachting van hoogopgeleide mannen is ruim 81 jaar, van hoogopgeleide vrouwen ruim 85 jaar. Gemiddeld leven lager opgeleiden 6 tot 7 jaar korter dan hoogopgeleiden. Belangrijk is voorts dat een lager opleidingsniveau niet alleen verlies van jaren, maar ook toename van ongezonde jaren betekent. Voor wat betreft sociaaleconomische status en

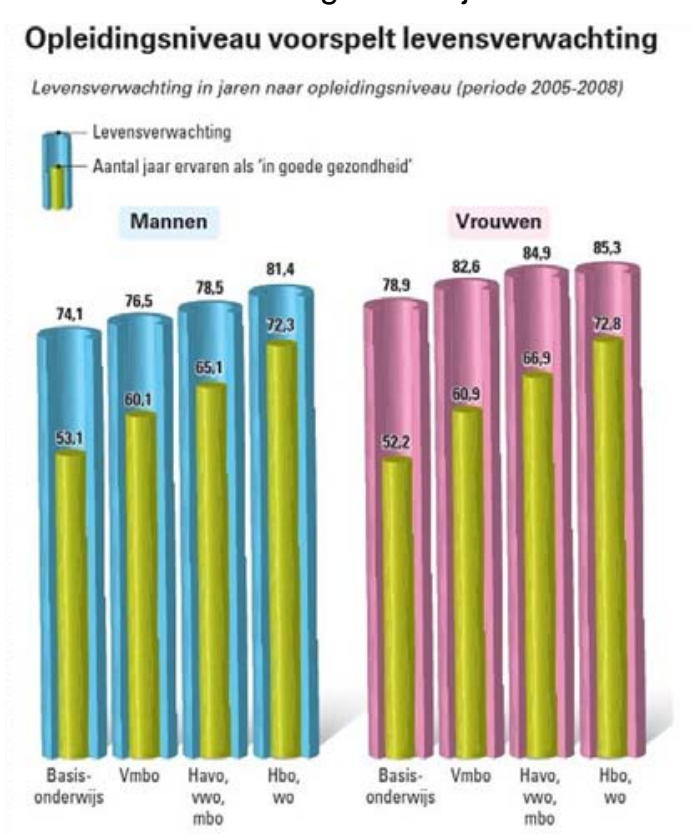

opleidingsniveau doet Nederland echter niet onder voor de rest van Europa. In tegendeel zelfs. Met de Scandinavische landen zijn in Nederland de sociaaleconomische verschillen lager dan elders. Egalitaire samenlevingen worden juist gekenmerkt door een betere gezondheidstoestand en een langere levensduur $^{3}$. Dus dat kan de lagere levensverwachting van de Nederlander niet verklaren.

Werd in de negentiende eeuw de levensduur vooral bepaald door gebrekkige hygiëne en deplorabele woonomstandigheden, tegenwoordig wordt deze vooral bepaald door biologische factoren als genetische aanleg, leefstijl en omgevingsfactoren. Een ongezonde leefstijl veroorzaakt ongeveer een kwart van de ziektelast in ons land. Daarbij gaat het dan vooral om roken en te veel vet en zout in de voeding leidend tot kanker, hart- en vaatziekten, diabetes en chronisch longlijden. Roken is de belangrijkste oorzaak voor verloren levensjaren door een ongezonde leefstijl.

In vergelijking met de landen om ons heen wordt er in Nederland meer gerookt. De afgelopen jaren is door tal van maatregelen het aantal rokers gedaald. Ook in Nederland. Maar niettemin is het aantal rokers in Nederland nog steeds hoger dan in de landen om ons heen. Dit komt onder meer omdat in Nederland sigaretten gemakkelijk verkrijgbaar zijn en ondanks periodieke prijsstijgingen nog steeds betaalbaar zijn voor iedereen. Het rookgedrag van de Nederlander is dan ook zeker één van de redenen waarom de levensverwachting lager is dan in de rest van West-Europa. In dit licht is het onbegrijpelijk dat in Nederland in weerwil van internationale afspraken het tabaksontmoedigingsbeleid is versoepeld en in kleine café's weer gerookt mag worden. De gevolgen daarvan blijven ook niet uit. Sinds kort stijgt het aantal rokers in Nederland weer.

Roken is echter niet de enige reden voor de achterblijvende levensverwachting. Andere redenen zijn onder meer dat de overheid zich tot nu toe niet verantwoordelijk voelde voor leefstijlbeïnvloeding en een voorkeur heeft voor keuzevrijheid van het individu. Daar waar wel geïnvesteerd wordt in preventie, liggen de prioriteiten niet daar waar het moet. Voorts verhinderen de zogenaamde schotten in de zorg een effectief continuüm tussen cure, care, gezondheidsbevordering en preventie.

\section{Voorbeeld 2}

De Nederlandse bevolking vergrijst in rap tempo. Nederland telde in 2011 ruim 2,6 miljoen 65plussers, wat $15,6 \%$ van de totale bevolking is, en bijna 650.00080 -plussers. Dit aantal zal de komende jaren blijven stijgen. In 2040 is 25,9\% van de bevolking 65+, dat zijn 4,6 miljoen mensen. Limburg loopt in de vergrijzinggolf met de provincies Friesland en Groningen voorop. Al in 2025 zal bijna een kwart van de Limburgse bevolking ouder zijn dan 65 jaar.

Hoewel veel ouderen tegenwoordig gezond en fit zijn, zijn velen dat ook niet. Circa $60 \%$ van personen ouder dan 75 jaar heeft een chronische aandoening als hartfalen, diabetes, of COPD. De helft daarvan meer dan één. Juist de combinatie van meer dan één chronische aandoeningen creëert specifieke zorgproblemen. Dat wordt het best geillustreerd in een brief die ik enkele jaren geleden ontving van een patiënt naar aanleiding van een interview in Trouw, waarin ik sprak over de problematiek rond meervoudige chronische aandoeningen bij ouderen. Deze brief luidde als volgt:

'Immers, een 70-jarige oudere, onderhevig aan diverse kwalen en dus onderworpen aan de grillen van 4 specialisten plus een huisarts (en zijn bazige assistente) ben ik een deskundig vertegenwoordiger van het veld.... Je woorden in het paginagrote artikel zijn mij uit het hart gegrepen. Er is inderdaad niet 
één medicus die een totaalbeeld heeft van zijn meerkwalige, oudere patiënt. En ja, een internist zou een mogelijke coördinator kunnen zijn, maar in feite kun je daar als patiënt maar enkele keren per jaar terecht voor hooguit tien minuten'

In dit relaas wordt het dilemma van de gezondheidszorg die meer en meer ouderenzorg wordt, helder geschetst. Toenemend gefragmenteerde zorg door voortschrijdende specialisatie waar juist generalisatie nodig is, daardoor ontoereikende afstemming en regie, en voorts onvoldoende tijd voor zorg op maat. Els Borst bestempelde dat destijds als een tekort aan kijk- en luistertijd.

Maar vergrijzing is niet de enige verandering in de zorgvraag. De zorgvraag neemt ook toe door meer ontwikkelingen in de medische technologie, meer aandacht voor gezondheidsbevordering en primaire preventie, meer aandacht voor functioneren naast ongemak door ziekte en toenemende culturele diversiteit van de bevolking. Voorts verandert de zorgvraag ook door de invoering van interdisciplinaire en transmurale zorgketens en toepassing van e-Health. Dit lijstje is zeker niet volledig.

De vergrijzing van de bevolking heeft echter nog een effect. In combinatie met een achterblijvend geboortecijfer neemt de komende jaren de beroepsbevolking af. Op dit moment is het aandeel van de beroepsbevolking op de totale bevolking circa $65 \%$. De komende jaren zal dit percentage dalen naar $60 \%$. Op termijn zelfs naar $50 \%$. Verhoging van de pensioengerechtigde leeftijd zal deze daling iets doen vertragen, maar niet voorkomen. Dat betekent dat de komende jaren door een zogenaamde dubbele vergrijzing van de bevolking, de toegenomen zorgvraag door minder mensen moeten worden opgevangen en dat zieken en hulpbehoevenden toenemend een beroep zullen moeten doen op vrijwilligers in de directe omgeving.

\section{Voorbeeld 3}

Niet alleen de zorgvragen nemen toe, de zorgkosten ook. Dit komt vooral door de stijgende zorgvraag als hiervoor besproken, en omdat door technologische ontwikkelingen steeds meer mogelijk wordt.

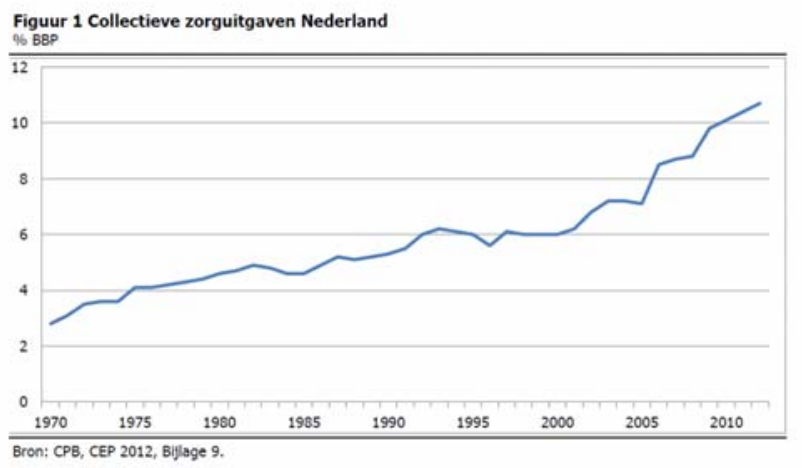
Door verschillende politieke partijen wordt bij herhaling opgemerkt dat er daardoor sprake is van een explosieve stijging van de zorgkosten. In de afgelopen jaren zou deze nog versterkt zijn door invoering van marktwerking in de zorg. Daarbij wordt dan vaak verwezen naar plaatjes zoals hiernaast afgebeeld en waarin de curve vooral in de jaren na 2005 een forse stijging laat zien. U moet zich echter realiseren dat het hier gaat om het percentage bruto binnenlands product. Dat percentage stijgt ook wanneer bij gelijkblijvende kosten het bruto binnenlands product afneemt. En dat is de afgelopen jaren als gevolg van de eurocrisis zeker het geval geweest. De werkelijke stijging van de zorgkosten is de laatste jaren niet veel anders dan de jaren daarvoor. Interpreteren van curves blijft moeilijk, ook voor politici.

Niet ontkent kan echter worden dat de kosten van de zorg in Nederland hoog zijn, na de Verenigde Staten zelfs hoger dan in elk ander westers land. Op dit moment wordt bijna $12 \%$ van het bruto binnenlands product besteedt aan de zorg. Bij ongewijzigd beleid zal dit de komende jaren doorstijgen naar $15 \%$. Inmiddels beslaan de zorguitgaven meer dan een kwart van de totale collectieve uitgaven. Daarmee is de zorg bijna de grootste post van de overheidsbegroting, en binnen enkele jaren de grootste. Maar dat komt niet door de curatieve zorg, wat vaak wel wordt gedacht.

Ik merkte al op dat de curatieve zorg in Nederland sober en efficiënt is. De kosten van curatieve zorg betreffen in Nederland circa 4\% van het BBP en zijn daarmee lager dan in de landen om ons heen en stijgen ook niet opvallend sneller. Het echte probleem zit in de langdurige zorg. In vergelijking met de landen om ons heen geeft Nederland vooral meer uit aan collectief gefinancierde langdurige zorg. Nederland besteedt daaraan $8 \%$ van het bruto binnenlands product, tegenover $4 \%$ in andere Europese landen. Dat komt onder meer doordat Nederlanders veel minder zelf de zorg voor hun ouderen op zich nemen. Ouderenzorg is in Nederland vooral een publieke voorziening, en dat is duur. 
Bij ongewijzigd beleid wordt daarom vooral de ouderenzorg onbetaalbaar. En door een tekort aan personeel ook onuitvoerbaar.

Er bestaat dus een aantal problemen. De zorgvraag neemt toe, terwijl personeel en middelen afnemen. De zorgorganisatie en -bekostiging zijn versnipperd. Vooral de ouderenzorg is duur en op termijn onbetaalbaar. Er is geen samenhang tussen publieke zorg en $1^{\mathrm{e}}$ en $2^{\mathrm{e}}$ lijns zorg. Er is een toenemende discrepantie tussen het zorgaanbod en de zorgvraag, deels door toenemende specialisatie ten koste van generalisatie. Er is onvoldoende tijd voor aandacht voor de patiënt, deels omdat de financiering van de zorg meer gericht is op productie dan op zorguitkomsten. En dan laat ik de problematiek rond marktwerking in de zorg en mogelijke winstuitkering in de zorg nog ongenoemd.

Tegelijkertijd staat de zorg ook voor grote uitdagingen. Meer moet met minder. Er is toenemend behoefte aan zorg op maat. Meer zorg voor de zieke dan voor de ziekte. Meer zorg wanneer noodzaak in plaats van zorg op afspraak. Want hoe vaak komt het niet voor dat een patiënt met een chronische meervoudige aandoening op een lang te voren gemaakte afspraak op het spreekuur verschijnt terwijl er weinig aan de hand is en dat dan blijkt dat er enkele weken daarvoor juist van alles mis was. Voorts meer aandacht voor gezond gedrag en voorkomen van ziekte en ongemak. Én meer verantwoordelijkheid bij de patiënt. Een paradigmashift in de zorg is dus dringend noodzakelijk.

De afgelopen jaren heeft de KNMG zich nadrukkelijk geroerd in de discussie over noodzakelijke aanpassing van het zorgstelsel. Voor de KNMG is de patiënt daarin steeds het uitgangspunt geweest, indachtig een uitspraak van William Murphy die ik gedurende mijn opleiding wekelijks tijdens klinische conferenties in de collegezaal van de afdeling Interne Geneeskunde heb kunnen lezen: The patient is the centre of the medical universe around which all our work revolves and towards which all our efforts tend.

Daarbij moet het dan gaan om zorg die veilig is en van goede kwaliteit, goed toegankelijk en bereikbaar, meer optimaal dan maximaal, meer geïntegreerd dan gefragmenteerd, goedkoop waar het kan en duur waar het moet, dichtbij huis waar mogelijk en verder weg waar noodzakelijk, gericht op bevordering van gezondheid en participatie naast behandeling van ziekte, met aandacht voor functioneren naast ongemak en weloverwogen keuzes in de zorg.

Om dit te bereiken is het noodzakelijk dat de zorg meer dan dat nu het geval is rond de patiënt georganiseerd wordt. Dat door invoering van integrale bekostiging de schotten tussen de eerste- en tweedelijn worden geslecht en dat door inrichting van een anderhalvelijnszorg een beter continuüm daarin kan worden gerealiseerd. En voorts dat de vervolgopleidingen waar mogelijk en zinvol meer in lijn met zorgvragen dan aan de hand van een disciplinaire ordening worden ingericht. Met een betere balans tussen generalistische en specialistische zorg en taakherschikking waar zinvol en verantwoord.

Ten behoeve van de kabinetsformatie zijn deze onderwerpen afgelopen zomer in een 'Agenda voor de zorg' nader uitgewerkt. Dit was een gezamenlijk initiatief van vertegenwoordigers van consumenten, patiënten, zorgaanbieders, zorgverleners en zorgverzekeraars. Zij deden daarin gezamenlijk een aanbod aan het nieuwe kabinet om de zorg verder te verbeteren en daardoor een belangrijke bijdrage te leveren aan beheersing van de zorguitgaven. De KNMG heeft in de opstelling van deze Agenda een belangrijke rol gespeeld. De kracht van deze Agenda ligt in een integrale aanpak van de gezondheidsproblematiek over sectoren heen. Een belangrijk onderdeel daarin is een noodzakelijke hervorming van de langdurige zorg, waarin cliënten meer eigen regie en meer verantwoordelijkheid krijgen om zelf en met hun omgeving tot oplossingen te komen. Professionele zorg wordt in het verlengde hiervan aangeboden, waarbij de nadruk komt te liggen op kwaliteit van leven in plaats van zorg. In de Agenda wordt terecht gesteld dat het huidige stelsel deze paradigmashift belemmert. De initiatiefnemers willen daarom de behandeling, verpleging en verzorging van ouderen en chronisch zieken overhevelen van de AWBZ naar de Zorgverzekeringswet, zodat de zorg aan deze doelgroep integraal en in een continuüm kan worden georganiseerd. Als gevolg daarvan kan de AWBZ dan weer teruggaan naar waar deze ooit voor bedoeld was: een publieke verzekering voor langdurige onverzekerbare zorg, zoals de gehandicaptenzorg.

Voorts worden in de Agenda voorstellen gedaan om meer aandacht aan preventie en gezond gedrag te geven, ongepast en ondoelmatig gebruik van zorg terug te dringen en de organisatie van de zorg te vernieuwen. 
In de Agenda wordt ook gepleit voor een bekostigingssysteem dat zorgaanbieders meer beloont voor kwaliteit en gezondheidsuitkomsten in plaats van handelingen, verrichtingen en indicaties, zodat ongewenste volumeprikkels worden gecorrigeerd.

In het regeerakkoord van het recent aangetreden kabinet is een aantal van de voorstellen van de Agenda voor de zorg overgenomen. Maar een aantal helaas ook niet. Positief is dat het regeerakkoord duidelijk de nadruk legt op preventie en een gezonde leefstijl en het kabinet dat nu ook actief wil ondersteunen. En dat moet ook. Bij preventie zijn populatiemaatregelen effectiever dan een beroep op de individuele verantwoordelijkheid, zeker wanneer het om ongezonde leefstijlen gaat die door een sociale context of verslaving worden onderhouden. Maar hoe het kabinet dit wil gaan doen is overigens volstrekt onduidelijk.

Positief in het regeerakkoord zijn ook de accentuering van samenwerken in de zorg in plaats van enkel concurreren, het meer willen sturen op zorguitkomsten dan zorgproductie, verdere versterking van de eerstelijnszorg, en het respecteren van de akkoorden die met de eerste en tweede lijn en GGZ zijn gesloten. Positief is ook dat het kabinet kiest voor hervorming van de langdurige zorg. Daarin wordt echter gekozen voor een andere aanpak dan in de 'Agenda voor de zorg' is voorgesteld. Het kabinet wil dat de AWBZ wordt omgevormd tot een landelijke voorziening voor intramurale zorg voor ouderen en gehandicapten. De verantwoordelijkheid voor AWBZ-zorg die nu thuis of in de directe omgeving wordt geleverd wil het kabinet in afgeslankte vorm bij de gemeenten leggen. Hierdoor blijft de zorg voor ouderen gefragmenteerd. En bestaat er voorts een reëel risico dat de zorg voor mensen met een ernstige beperking, ouderen en chronische zieken die nog thuis wonen meer een voorziening dan een recht wordt. Per gemeente kan dit dan onderwerp van discussie worden indien binnen beperkte middelen keuzes moeten worden gemaakt. Dan kan het zo maar gebeuren dat onderdelen van ouderenzorg worden uitgeruild tegen meer straatverlichting of meer peuterspeelplaatsen.

Zo zijn er meer kritische opmerkingen te maken. En dan denk ik niet aan de soap die na de dubbele beëdiging rond de inkomensafhankelijke premie werd uitgerold. In het regeerakkoord wordt node een visie over patiëntgerichte zorgverlening en ontschotting van de zorg gemist. In mijn ogen is daarvoor integrale bekostiging met regionale budgettering waarin zorgpartijen gezamenlijk afspraken maken over wie wat gaat doen essentieel. De organisatie en bekostiging van de zorg dienen integrale zorg te bevorderen, en niet in de weg te staan, zoals dat nu het geval is. De visie die dit kabinet mist is gelukkig wel aanwezig in Zuid Limburg waar binnenkort met het project Blauwe Zorg geëxperimenteerd gaat worden met populatiebekostiging met één budget voor de huisartsen en de ziekenhuizen in de regio en een collectieve verantwoordelijkheid om daar verstandig mee om te gaan.

Tenslotte, de kans dat winstuitkering in de zorg mogelijk wordt blijft bestaan. In beginsel heb ik niets tegen winstuitkering in de zorg. Maar dat moet dan wel leiden tot zorginnovatie, kwaliteitsverbetering en betere dienstverlening, zonder toename van kosten. En daar zit nu juist de kneep. Er is de afgelopen jaren een groot aantal wetenschappelijk onderzoeken gepubliceerd waarin de kosten en zorgkwaliteit van for-profit en not-for-profit instellingen worden vergeleken. Vrijwel zonder uitzondering tonen deze onderzoeken aan dat een for-profit benadering in de zorg leidt tot hogere kosten en lagere kwaliteit. Ik kan er niets aan doen, dit is een evidence-based constatering.

Ik kan dit aan de hand van een aantal meta-analyses illustreren ${ }^{4}$. Daarin zijn verschillende studies samengevat waarin de kosten van private for-profit en not-for-profit zorginstellingen zijn vergeleken. In de for-profit instelling ging het hierbij om een winstuitkering van circa $6 \%$ van de investering. In 6 van de 9 geanalyseerde studies bleek dat te leiden tot hogere kosten. In geen van de studies tot lagere kosten.

Een andere studie laat zien dat in for-profit instellingen de winstuitkering onder meer werd bereikt door te bezuinigen op de kwaliteit van de staf ${ }^{5}$. Onverwacht is dat overigens niet. Personeelskosten zijn immers de hoogste kostenpost in een zorginstelling.

Een derde studie, tenslotte, toont het mortaliteitsrisico bij acuut opgenomen patiënten in for-profit en not-for-profit instellingen ${ }^{6}$. In het merendeel van de in deze anayse opgenomen studies lijkt het relatieve sterfterisico in for-profit instellingen hoger dan of gelijk aan not-for-profit instellingen, zeker niet lager. In de publicatie wordt er daarvoor een aantal verklaringen gegeven. Onder meer het aantal 
verpleegkundigen per opnamebed, het opleidingsniveau van de verpleegkundige staf, de turnover en de kwaliteit van het materieel.

Dit zijn waarnemingen die anders zijn dan wat je intuïtief zou verwachten. Maar begrijpen doe ik het wel. Voorstanders van winstuitkering in de zorg verwachten dat met extra vreemd kapitaal meer innovatie, kwaliteitsverbetering en doelmatigheid kan worden bereikt. En daar moet het ook om gaan. Maar kapitaalinvesteerders hebben een ander motief om te investeren in de zorg. Zij zien de zorg als middel om rendement te halen uit hun investering. Waarom zouden zij dat anders doen? Tussen zorgaanbieders en kapitaalinvesteerders bestaan er dus verschillende opvattingen over de middelen en doelen in de zorg. Kennelijk wint de zorg om rendement het in een for-profit benadering van de zorg om kwaliteit. Precies wat de eerder genoemde wetenschappelijke onderzoeken concluderen.

Dit is overigens geen pleidooi tegen marktwerking in de zorg. Sowieso vraag ik mij af of er in de zorg wel echt sprake is van marktwerking. Zorgverzekeraars hebben een acceptatieplicht. Premiedifferentiatie bij chronische ziekte of ongezond gedrag mag niet, en terecht. Met het afsluiten van de hoofdlijnakkoorden voor de eerste- en tweedelijn en de GGZ is de bovenkant van de zorgkosten gebudgetteerd. Dat past allemaal niet in echte marktwerking. In de zorg spreekt men dan ook graag over gereguleerde marktwerking. Maar ook dan blijt het een containerbegrip waar men niet zomaar voor of tegen kan zijn. Minister Schippers heeft wel eens voorgesteld het begrip marktwerking in de zorg niet meer te gebruiken en de onderwerpen die men rekent tot marktwerking gewoon bij de naam te noemen en daar afzonderlijk over te spreken. Daar ben ik het mee eens. Maakt de discussie over wel of niet marktwerking en waar en hoe wel zo eenvoudig én genuanceerder.

Ik vind dat de discussie ook niet primair over wel of niet marktwerking moet gaan. De discussie moet gaan over wat de beste manier is om goede en betaalbare zorg te realiseren die toegankelijk is voor iedereen. Indien dat met bepaalde vormen van marktwerking te bereiken is, wat mij betreft prima. Het moet in de zorg toch vooral om de inhoud gaan, minder over de vorm zolang dat de kernwaarden van onze gezondheidszorg niet aantast.

Er bestaat bijvoorbeeld geen verschil van mening dat een duurzame arts-patiëntrelatie de kurk is waarop de eerstelijn drijft. Daarin past concurrentie tussen huisartsen waarbij patiënten heen en weer kunnen hoppen niet. Het financieringsmodel voor de tweedelijn kent nogal wat productieprikkels, maar door de hoofdlijnakkoorden zijn die van hun onbeheersbaarheid ontdaan. En dat blijkt ook, want de zorgkosten in de cure stabiliseren. Niet door marktwerking, maar door de afspraken die met de eersteen tweedelijn zijn gemaakt.

ledereen is het er over eens dat het beter is om de zorg te financieren op basis van uitkomstmaten. Ongeacht of het daarbij dan gaat om parameters voor gezondheidswinst, patiënttevredenheid of afname van de ziektelast. Lastig te implementeren, maar gaat er gezien de afspraken in het regeerakkoord nu echt komen. Er bestaat ook weinig bezwaar tegen selectieve zorginkoop of een bonus-malusbeloning door zorgverzekeraars. Kan marktwerking genoemd worden, maar ook kostenen doelbewust handelen.

Ik heb dan ook geen moeite met bepaalde vormen van marktwerking, zolang het samenwerking maar niet in de weg staat en betaalbare en toegankelijke zorg voor iedereen gegarandeerd is. Voor de patiënt 'towards which all our efforts tend'.

Dames en heren studenten en assistenten in opleiding tot specialist, een belangrijk deel van mijn universitaire loopbaan heb ik gewijd aan onderwijs. Ik heb mij er altijd over verbaasd dat in academische kringen vaak gesproken wordt over onderwijslast, in plaats van onderwijslust. Met onderwijs bezig zijn is leuk, vooral in kleinschalig verband en interactief. Werken met jonge mensen is inspirerend. Als ik iets van mijn opleiders heb geleerd, dan is het dat in de zorg de patiënt centraal staat en dat onderwijs en onderzoek de peilers zijn waarop de zorg steunt. De patiënt moet kunnen rekenen op optimale zorg, en dat is iets anders dan maximale zorg. Om de zorg optimaal te houden zijn wetenschappelijk onderwijs en onderzoek essentieel. Onderzoek is er om de zorg te vernieuwen en te verbeteren. Onderwijs is er om de resultaten van wetenschappelijk onderzoek te vertalen in de praktijk én om de continuïteit van de zorg te borgen. $U$ en ik zijn slechts passanten in het continuüm van de zorg. Onderwijs is de schakel tussen de zorg vandaag en de zorg morgen. Een arts kan wetenschappelijk onderzoek aan anderen overlaten, onderwijs rond patiënten bij voorkeur niet. 
Als arts heeft $u$ straks een belangrijke maatschappelijke verantwoordelijkheid. Patiënten zullen hun zorg aan $\mathrm{u}$ toevertrouwen. Zij moeten er op kunnen rekenen dat $\mathrm{u}$ die zorg onafhankelijk verleent. Met andere woorden, dat $\mathrm{u}$ zich bewust bent van uw professionele verantwoordelijkheden en professionele autonomie en daar ook naar handelt. Eenvoudig is dat niet. Vooral over de begrippen professionele verantwoordelijkheid en professionele autonomie bestaan er nogal wat misverstanden. Ondanks het feit dat er over deze onderwerpen al jaren wordt gediscussieerd. Elke aanstaande arts raad ik aan om het artikel 'De maatschappelijke positie van de arts' te lezen dat de Amsterdamse sociaalgeneeskundige Arie Querido in 1958 heeft geschreven ${ }^{7}$. Dit artikel is te vinden in de bundel 'Werk in uitvoering' dat in 1970 ter gelegenheid van het afscheid van Querido is gepubliceerd. Veel wat er in die bundel staat is nog steeds actueel.

Het artikel over de maatschappelijke positie van de arts begint met de vragen 'Waarom hebt $u$ de studie geneeskunde gekozen, en waarom wilt u dokter worden?' En benadrukt vervolgens dat het artsenberoep een prachtig vak is, maar dat het ook tot teleurstelling kan leiden. Onder meer wanneer men zich verliest in een aantal hardnekkige fabels waarmee het artsenberoep ook nu nog is omgeven. De eerste fabel is dat het vroeger anders - lees: beter - was. Dat de arts vroeger groot maatschappelijk aanzien genoot en een fors inkomen had. Dat is niet zo. Voor zover artsen in het verleden maatschappelijk aanzien genoten, dan had dat meer met hun afkomst dan hun beroep te maken. Een goede afkomst was ook nodig want het beroep zelf leverde weinig op, materieel noch immaterieel.

Napoleon was de eerste die legerartsen de rang van officier gaf. Voordien waren zij onderofficieren. Franse officieren weigerden niettemin met de officier van gezondheid van gelijke rang aan tafel te eten. In de negentiende eeuw werd de arts meer als een intellectuele bediende gezien dan lid van de aristocratie. Dat nadien het aanzien van de arts is gestegen heeft dan ook meer te maken met de kunst en kunde die hij of zij ontwikkeld heeft door wetenschappelijk onderzoek dan het beroep zelf. Zo was het vroeger en zo is het ook nu. De patiënt legt zijn of haar vertrouwen in uw handen. Een vertrouwen dat te voet komt, maar te paard gaat, wanneer door gebrek aan toewijding en kunde geschaad.

De tweede fabel is dat de arts uit hoofde van zijn beroep een bijzondere vrijheid geniet. Ook daarover bestaan er nog steeds veel misverstanden. Het begrip vrij beroep kent zijn oorsprong in de artes liberales van de Romeinen. Kenmerk daarvan was de zuivere wetenschapsbeoefening waartoe muziek, dichtkunst, welsprekendheid, spraakkunst, geschiedenis, filosofie, wiskunde en astronomie gerekend werden. Geneeskunde echter niet. Geneeskunde werd door de Romeinen gerekend tot de operae liberales. Daarbij was niet alleen van belang wat werd gedaan, maar vooral hoe en door wie. De operae liberales waren werkzaamheden die door de vrije man werden verricht. Werd hetzelfde werk gedaan door een onvrije, dan was het slavenwerk. Voor de Romeinen kon geneeskunde geen slavenwerk zijn. Ondenkbaar was immers de do ut des verhouding. Dat wil zeggen: ik geef arbeid opdat gij loon geve. Want een dergelijke contractuele verhouding betekende onvrijheid wat strijdig was met de voor de zorg noodzakelijk geachte operae liberales. De arts ontving van de Romeinen voor zijn diensten dan ook geen loon, maar een honorarium, een ereloon waarvan het kenmerk was dat het niet bij overeenkomst was bedongen. Zo is het nu natuurlijk niet meer. Artsen werken thans in dienstverband of zijn vrijgevestigd. In beide situaties krijgen zij een vergoeding voor geleverd werk op basis van afspraken. Querido geeft dan ook een andere definitie van het vrije beroep die mijns inziens niets aan actualiteit verloren heeft en die los staat van of de arts in loondienst werkt of vrijgevestigd is. Querido acht het kenmerkende van het vrije beroep dat het om een beroep gaat waarbij de kwaliteit van het werk en de resultaten daarvan een belangrijke verantwoordelijkheid impliceren die slechts door degenen die het werk verrichten gedragen kan worden. Voor de arts geldt dat hij voor zijn gedrag, zijn beslissingen en zijn handelingen zelf verantwoordelijk én aanspreekbaar is. En dat kan ook niet anders. Dit is het meest wezenlijke kenmerk van de arts-patiënt relatie en ook het meest wezenlijke kenmerk van het artsenberoep. Waar het in het vrije beroep dus om gaat is dat u er in uw werkzaamheden van verzekerd moet zijn dat uw verantwoordelijkheden en professionele onafhankelijkheid, binnen de grenzen van wat maatschappelijk verantwoord is, gegarandeerd zijn. Ongeacht of $u$ werkzaam bent in dienstverband of als vrijgevestigd arts. Want in beide situaties kan vrijheid tot onvrijheid leiden wanneer de contractuele verhoudingen of verdiensten een onafhankelijk en vrij functioneren in de weg staan.

Illustratief in dit kader vind ik het schilderij van Anne-Louise Girodet waarin Hippocrates een gift van de Perzische koning Artaxerxes afwijst. Hippocrates was in Griekenland beroemd geworden door 
onder meer bestrijding van de pest. De Perzen hadden hem daarvoor ook nodig en boden hem grote schatten aan wanneer hij bereid was om naar Perzië af te reizen. Hippocrates weigerde, want Griekenland gaf hem alle mogelijkheden om te zijn wat hij wilde zijn: arts voor de patiënten die hem hun zorg toevertrouwden, ongeacht wat hij daarmee kon verdienen. Hij vreesde dat hij die vrijheid in Perzië zou verliezen wanneer hij zich meer zou laten leiden door de verdiensten dan de inhoud van zijn vak. In de hal van Domus Medica staat een beeld dat herinnert aan het verzet van artsen in de Tweede Wereldoorlog. Dit beeld draagt als titel: Alleen een vrij mens kan een goed geneesheer zijn. Dat gold toen, maar ook nu. Hoe paradoxaal het ook klinkt, ik heb mij als arts in dienstverband altijd vrij in mijn handelen gevoeld, juist omdat wat ik deed onafhankelijk was van wat ik daarmee verdiende. Ik wens u een zelfde vrijheid van handelen toe.

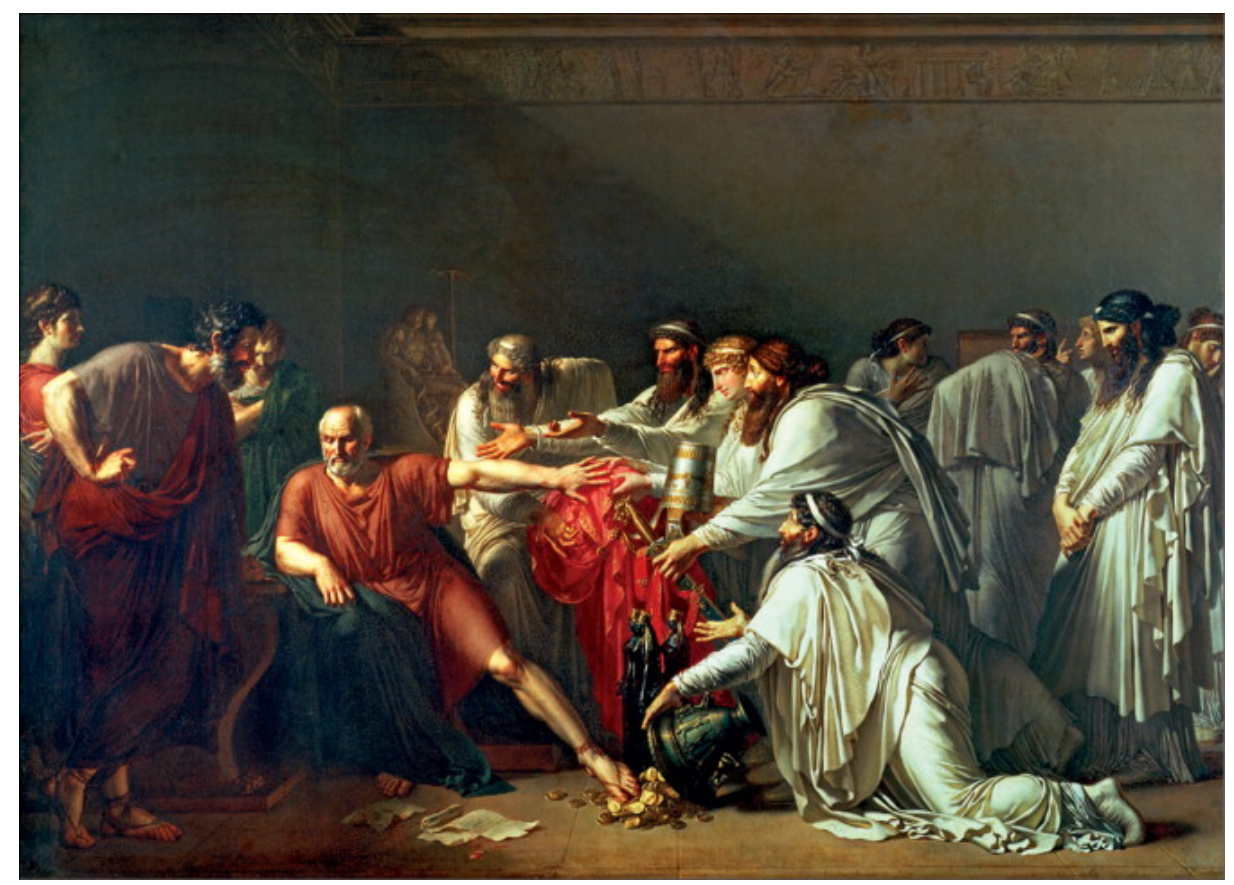

Mijnheer de rector, ik heb tijdens mijn loopbaan kunnen ervaren hoe belangrijk rolmodellen zijn. Ik heb er gelukkig veel gehad. De eerste was mijn vader die medio dit jaar is overleden. Destijds was hij gynaecoloog in de Emmakliniek in Den Haag. In mijn eindexamenjaar nam hij mij tijdens kerstavond mee naar een bevalling. Die bevalling heeft een onuitwisbare indruk op mij gemaakt. Ik twijfelde in die tijd tussen Leiden en Delft. Maar nadien stond mijn besluit vast. Ik wilde medicijnen studeren in Leiden.

Mijn volgende rolmodel was de negentiende-eeuwse fysioloog Franciscus Donders, één der grondleggers van de interne geneeskunde. Donders heb ik uiteraard nooit ontmoet. Hij was echter de naamgever van het medisch dispuut waar ik mijn vrouw heb ontmoet en de patholoog Roelof Willighagen. Willighagen wees mij de weg naar de academie en zette mij op het spoor van de endocrinologie en initieerde mijn promotieonderzoek. Na zijn vertrek naar Maastricht in 1974 werd mijn proefschrift onder leiding van de pathologen Aart Schaberg en Gerard Bots afgerond.

Mijn opleider Jaap de Graeff was voor mij het toonbeeld van de internist. De kneepjes van het vak leerde ik echter van Marius van Zoeren tijdens mijn diensttijd in het militair hospitaal Dr A. Matthijsen in Utrecht. Dries Querido - de Leidse Querido - was mijn auctor intellectualis toen ik voorzitter was van de landelijke vereniging van assistent-geneeskundigen (LVAG). Gedurende mijn opleiding in de endocrinologie kon ik mij spiegelen aan Don Smeenk, Janke Terpstra en Michiel Krans. Daarna in het Bartholomew's hospital in Londen aan Mike Besser, Lesley Rees, Phil Lowry en lan Doniach. Naast Willighagen is echter het meest beslissend voor mijn loopbaan Guus Flendrig geweest, het eerste hoofd van de academische kliniek Interne Geneeskunde in Maastricht. 


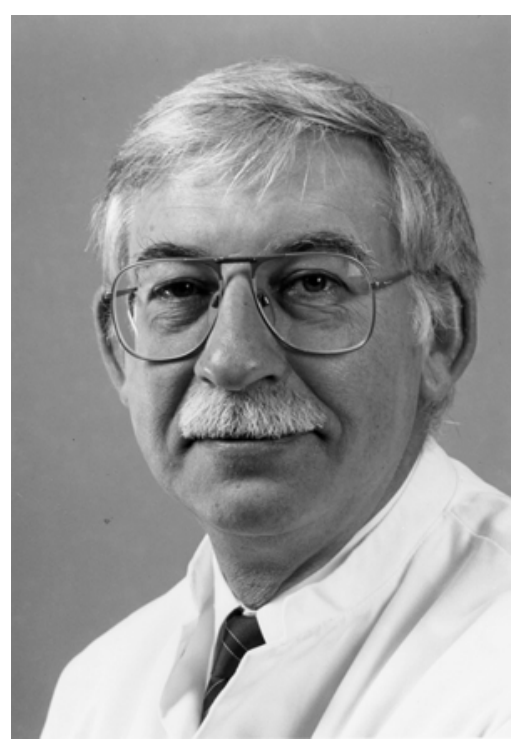

Guus belde mij medio 1986 met de vraag of ik geïnteresseerd was in een overstap naar Maastricht. Ik was daar aan toe, zo had hij via via begrepen. Een middag lang spraken Guus en ik over de problemen van de nog jonge afdeling Interne Geneeskunde. Stuk voor stuk vond ik dat uitdagingen. Vervolgens gingen wij via de Sterre der Zee naar restaurant 't Kloaske voor het diner. Daar werd ik gekeurd door José en verder door Guus ingepakt. Eén januari 1987 begon ik in het azM, de dag dat het ziekenhuis Annadal werd omgedoopt tot academisch ziekenhuis. Samen met Geert Blijham vormden wij het dagelijks bestuur van één afdeling Interne Geneeskunde met daarin subspecialistische werkgroepen. Guus hield van eggen en ploegen en was onvermoeibaar in het opstellen van regels en richtlijnen. En check en dubbelcheck. Maar met een menselijke maat. Onze echtgenotes kregen op hun verjaardag een bos bloemen thuisbezorgd. Te vroeg is Guus overleden. Zijn werk was niet af en is dat nog niet. Destijds was het voor hoofden van de onderafdelingen lastig om de balans te vinden tussen het belang van de eigen subdiscipline en het belang van afdeling als geheel. Nu is dat naar ik de indruk heb niet anders. Mijn opvatting is altijd geweest dat het eigen belang vooral gediend is met het algemeen belang. Dat met gemeenschappelijk doelen met de patiënt als uitgangspunt meer kan worden bereikt dan met een optelsom van afzonderlijke ambities. Guus zag zijn rol daarin dienend en initiërend. De veren liet hij aan ons en ik heb ervaren dat dat niet alleen figuurlijk maar ook letterlijk vleugels geeft.

Tijdens een aantal bestuurlijke functies heb ik Guus steeds in portret in de buurt gehad. Tijdens mijn decanaat, mijn rectoraat en mijn voorzitterschap van de KNMG. Niet zelden heb ik bij ingewikkelde problemen voor dat portret gestaan en mij afgevraagd hoe hij die zou aanpakken. Meestal kon ik dat wel raden. Wanneer het lastig werd en een besluit al dan niet geforceerd moest worden zei Guus vaak 'Geen enkel besluit is voor de eeuwigheid' of 'de tijd lost veel problemen op'. Ik vind het een eer dat ik mijn universitaire loopbaan in Maastricht met de Flendrig-lecture mag afsluiten.

Mijnheer de rector, ik kom aan de afsluiting van dit college. Het College van Bestuur wil ik danken voor het vertrouwen dat ik de afgelopen 26 jaar heb genoten. In deze periode heb ik vrijwel alle rollen en functies gehad die een universiteit kent. En met zeer veel plezier. Toen ik enkele maanden nadat ik naar Maastricht was vertrokken weer eens in Leiden kwam, vroeg men mij of ik er geen spijt van had vanuit de eredivisie in de derde klas zaterdagmiddagvoetbal terecht te zijn gekomen. Welnu, mijnheer de rector, de Universiteit Maastricht heeft mij alles geboden wat men zich in een academische loopbaan kan wensen. Ik heb dan ook geen moment spijt gehad van mijn keuze voor Maastricht. Ik heb het een voorrecht gevonden om een bijdrage te kunnen leveren aan de opbouw van de universiteit. In de Reviewcommissie werd het voorstel van de Universiteit Maastricht voor prestatieafspraken en toekenning van een selectief budget als 'zeer goed' beoordeeld. En terecht. De universiteit heeft zich de afgelopen jaren een vaste plaats verworven in de eredivisie van het universitaire landschap, lang voordat de andere universiteiten dat schoorvoetend begonnen in te zien. De UM vervult een voorbeeldfunctie in het universitair onderwijs en zal dat voorlopig ook wel blijven doen.

Leden van de Raad van Bestuur van het Maastricht Universitair Medisch Centrum, u dank ik voor de gelegenheid die mij geboden is om mij te wijden aan mijn liefde in het vak, de patiënt met een hormonale aandoening. De wijze waarop u mij na mijn rectoraat weer in uw midden heeft opgenomen heb ik als een welkom weerzien ervaren. Tijdens mijn decanaat was ik verklaard tegenstander van de UMC-vorming. Althans voor dat moment. Ik vond dat een UMC gevormd moest worden op basis van een gemeenschappelijke visie, niet als oplossing van een probleem, zoals dat bij het AMC was gebeurd. Die visie zou dan moeten gaan over de samenhang tussen patiëntenzorg en wetenschappelijk onderzoek en het wetenschappelijk onderwijs als verbindend element voor duurzame zorg. Onderzoekthema's die geïnspireerd zijn door zorgvragen van vandaag en morgen en topreferente functies die daarop aansluiten. Voor de vorming van een UMC vond ik een fusie van de faculteiten geneeskunde en gezondheidswetenschappen een voorwaarde. In de visie van een UMC in Maastricht zou het immers moeten gaan om het continuüm care en cure, aandacht voor het bevorderen van gezondheid, het voorkomen van ziekte en ongemak, en het verbinden van publieke en patiëntgerichte zorg. Wijlen Jan Carpay en ik waren het over veel onderwerpen oneens, maar 
daarover niet. Met respect denk ik terug aan de bijdrage van Jan Carpay aan de ontwikkeling van het academisch ziekenhuis Maastricht. Mede dankzij hem is de basis gelegd voor het MUCH-concept dat tijdens mijn rectoraat met Lou Brans Brabant, Mat Daemen, Harry Hillen, Cor Spreeuwenberg en Ingrid Wijk is geformuleerd.

Ik vind het nog steeds jammer dat bij de vorming van het MUMC niet gekozen is voor de naam MUCH dat stond voor Maastricht University Centre for Health. Daarmee had Maastricht zich kunnen onderscheiden van de andere UMC's in Nederland. Juist omdat de accentuering van gezondheid in de naam $\mathrm{MUCH}$ illustreert dat Maastricht al veel aandacht besteedde aan gedrag en gezondheid naast zorg voor ziekte, lang voordat de Raad voor de Volksgezondheid en Zorg dat op de nationale agenda plaatste. Gelukkig is er nu ook in Maastricht gekozen voor een UMC, hoewel het tempo waarin dat wordt gerealiseerd wel een tandje hoger mag. Ik verbaasde mij er eind vorig jaar over dat in de brief bij het kerstpakket de handtekening van de decaan ontbrak. Door het personeel en de media wordt nog steeds gesproken over het azM. In mijn ogen illustraties dat het MUMC er de jure wel is, maar de facto nog niet.

Mijnheer de rector, ik waag mij er niet aan om degenen te danken die mijn werkzaamheden aan deze universiteit zo bijzonder hebben gemaakt. Dat zijn er velen, en dan is de lijst al snel onbedoeld onvolledig. Een uitzondering wil ik maken voor Nicolaas Schaper, thans hoofd van de onderafdeling endocrinologie.

Bij mijn terugkomst na mijn rectoraat bleek de afdeling door een aantal ongelukkige ontwikkelingen danig ontregeld. De opleiding was ingetrokken en het wetenschappelijk onderzoek lag vrijwel stil. Met vereende krachten is het schip van de endocrinologie weer vlot getrokken. De sfeer is goed en er wordt door velen met plezier en hard gewerkt. Nicolaas Schaper komt daarvoor de eer primair toe. Hij beschikt over de waardevolle eigenschap om anderen ruimte te geven en kritiek te kunnen incasseren, sans rancune.

Dames en heren, ongeacht allen die mij in de afgelopen jaren hebben geïnspireerd, heb ik de meeste inspiratie ontvangen van mijn gezin. Van mijn kinderen, die mij mijn plek op hun tribune hebben gewezen. En Hieke, mijn zon in huis. Aan haar heb ik uiteindelijk alles te danken. Want zonder zon groeit er niets.

Ik heb meer dan genoeg gezegd, de finish is bereikt.

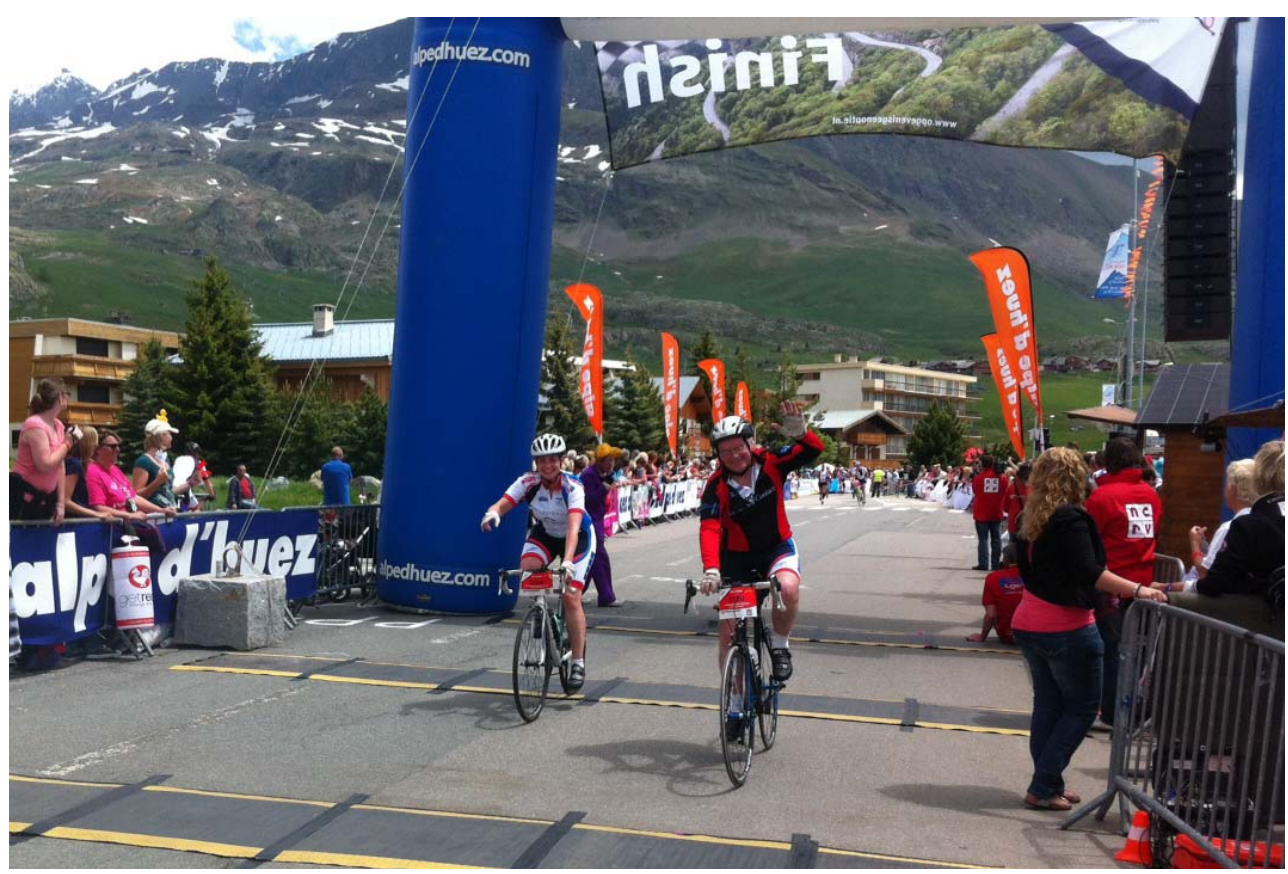


${ }^{1}$ Klikspaan. Student-typen. AW Sijthoff, Leiden, 1841

${ }^{2}$ Nussbaum M. Niet voor de winst. Ambo/Anthos, Amstedam, 2011

${ }^{3}$ Wilkinson RG, Pickett $\mathrm{K}$. The spirit society: why more equal societies almost always do better. Bloomsburry Press USA, 2009

${ }^{4}$ Devereaux PJ, Heels-Ansdell D, Lacchetti C, Haines T, Burns KE, Cook DJ, Ravindran N, Walter SD, McDonald H, Stone SB, Patel R, Bhandari M, Schünemann HJ, Choi PT, Bayoumi AM, Lavis JN, Sullivan T, Stoddart G, Guyatt GH. Payments for care at private for-profit and private not-for-profit hospitals: a systematic review and meta-analysis. CMAJ 2004;170:1817-24

${ }^{5}$ Comondore VR, Devereaux PJ, Zhou Q, Stone SB, Busse J, Ravindran NC, Burns K et al. Quality of care in for-profit and not-for-profit nursing homes: systematic review and meta-analysis. BMJ 2009; 339:b2732

${ }^{6}$ Devereaux PJ, Choi PT, Lacchetti C, Weaver B, Schünemann HJ, Haines T, Lavis JN, Grant BJ, Haslam DR, Bhandari M, Sullivan T, Cook DJ, Walter SD, Meade M, Khan H, Bhatnagar N, Guyatt $\mathrm{GH}$. A systematic review and meta-analysis of studies comparing mortality rates of private for-profit and private not-for-profit hospitals.CMAJ. 2002;166:1399-406.

${ }^{7}$ Romme MAJ, Gorter-Willemse WJZ (eds). Werk in uitvoering. Een keur uit de geschriften van Prof Dr A Querido, Amsterdam. HE Stenfert Kroese NV, Leiden, 1970 